DOI: 10.2478 /ausp-2021-0008

\title{
Suffering, Trauma, and Death in Anna Terék's Poetry Book Halott nók [Dead Women]
}

\author{
Magdalena GARBACIK-BALAKOWICZ \\ Institute for Literary Studies of the Research Centre for the Humanities \\ (Budapest, Hungary) \\ magdagarbacik@gmail.com
}

\begin{abstract}
Anna Terék is one of the most interesting Hungarian poets of the young generation. The study is focused on Terék's third poetry book, Halott nók (Dead Women) (2017). The book is a poetry cycle that shows stories/voices of five women. Violence, physical as well as psychological and symbolic, becomes destructive to the identity of the individual but also to the identity of the community. At the same time, it demands an effort of expression. The paper analyses these issues. The study describes the speech / narrative forms and their functions, and it examines the system of metaphors and the specific poetic language. The poems are closely related to the Yugoslav Wars. The study refers to this historical background but also shows the poems' universal dimension, which makes it possible to speak about them in terms of the life stories of today.
\end{abstract}

Keywords: Anna Terék, Hungarian literature, trauma studies, contemporary poetry

\section{Introduction}

In Anna Terék’s poetry book Halott nók (Dead Women) (2017), suffering, trauma, and death are shown as a constellation of different traumatized voices. The book consists of five monologue stories, all of which are thematically formed around the same themes. Each story describes the enormity of the suffering that the protagonists endure in their lifetimes, their entanglement in toxic relationships, and their inability to free themselves from them, a kind of inability that only death can break - since only death makes it possible for the protagonists to express their suffering in their own words and thus to reveal the intricacies of individual and collective trauma. The book is an evocation of pain, suffering, and death that can shock with its intensity. At the same time, it allows the reader to go beyond it, to exceed his/her own experience, and, thanks to that, to better empathize with other people. By doing this, the book draws attention to areas 
that tend to be ignored and marginalized in social discourses. The paper focuses on the structure, stylistic elements, and language by which this is achieved.

\section{Hybridity and Homogeneity, Individuality and Collectivity}

The very title, although brutal, precisely indicates not only the subject matter but also the lyrical subjects and their main characteristic, namely being dead. The book consists of five poetic cycles. These are: "Jelena", "Siberia”, "Maja”, "Judit", and "Island" - in each of them, the lyrical subject is of female gender. Each woman describes her death and life marked by suffering. The only exception is the last cycle, which also presents the story from the perspective of a man entangled in it. One is of the impression that, paradoxically, the protagonists' narratives show not life but its absence, because the fate of these women is filled with both physical suffering and emotional distress to such a great extent. The first voice belongs to Jelena, a Serbian mother who has lost her son during the war and commits suicide. The second part tells the dramatic fate of a young nameless woman, whose life forces her to move between Siberia, Paris, and Serbia. The third voice belongs to Maja, a young girl from Sarajevo, brutally killed by soldiers. We also meet Judit, a young cancer patient, who is trapped in a toxic relationship with her mother. The last part shows the story of a drowned nameless woman and her fanatically religious husband.

Such a radical gesture of giving a voice and possibility to self-express to a dead person - though death does not always mean physical death here - brings to mind the rhetorical figure of prosopopoeia. In classical rhetoric, this figure of speech was used to strengthen argumentation and to show a separate perspective on the discussed topic, thanks to which a more complete view of the problem became possible. The perspective of a dead person is particularly interesting. The classic literary example is the collection of Edgar Lee Masters, who in his Spoon River Anthology gives voice to the citizens of a provincial American town, creating a demystifying image of a small town society, based on crossreferential perspectives. In the case of Terék's book, this literary relationship is also emphasized (Görföl 2017, 121; Pataky 2017, 108). However, unlike Lee Masters's, Terék's characters do not know each other, they are not related, and there is no doubt that they are fictional.

It is clear, withal, that we are dealing with a well-thought-out concept of the entire book, in terms of not only the subject matter but also of the structure and language. The very structure of the poems is diverse - from the multi-page monologue of Jelena, the longest piece of the entire volume, to short, only a few lines long poems in the "Maja" cycle. Such a structure means that one can look at 
individual cycles as a conversation of individual voices and compare the whole to a mosaic, where every tiniest element has its place, but the meaning becomes fully visible only when looking at the whole book. And, although the described stories can be viewed separately and each poem can be interpreted individually, another possibility of reading opens up, where the boundaries of individual stories get blurred and the fates of individual characters permeate. This would mean that the analysis of individual poems necessarily remains incomplete because only the holistic interpretation of the entire book allows to achieve a comprehensive insight and reveals the multiperspectivity of the lyrical subjects. ${ }^{1}$

The poems describe the relationships between each of the women and their closest families. When we look closely at the plot elements and poetic structure, we notice numerous repetitions. This makes it possible to look at individual fates/ narratives as elements that build a specific vision of society along with relations within it. The picture of society becomes multilayered and complex. Some critics (Pataky 2017, 113) even argue that we can read Halott nók in line with the poetics of a family parable thanks to elements such as the social, historical, and geographic context, but also the repeated names of the protagonists and recurrent fragments of the plot. One such obvious repetition is linking the fate of Jelena and Maja - Jelena's father turns out to be one of Maja's persecutors. Next, we can list the theme of the sea and the character of Pavle, who seems to be the same person in two cycles - in "Maja", the girl's father is named Pavle, and in the poem "The Sea of My Dad" we read: "Before he moved to Sarajevo, / my dad was a fisherman and was very hairy. / Mum says, / his beard hung down totally into the water, / the sea urchins were stuck in his long hair" (Terék 2017, 79). ${ }^{2}$ In the "Island" cycle, the name of the woman's lover is Pavle; he is a fisherman with a beard that grows longer and longer after her death. The third example is the one of Judit's father, whose name is Ivan, the same as the partner of the nameless Russian woman from the "Siberia" cycle.

Such small elements at the plot level, along with repeated motifs and metaphors, only emphasize the impression of homogeneity of the whole book. Also thanks to this, the narrative is a reference not only to one specific history of trauma - ways of experiencing it and attempts to process it - but also to the social reality with its specific determinants. And although the individual stories take

1 This mosaic character is further emphasized by the graphics complementing the book created by László Antal - selected motifs / phrases of few poems, although initially connected with the narration, are reworked in such a way that they give a universal picture of the story told. The graphics are present in the Hungarian edition of the poetry book.

2 The translations from Terék's poems are my own throughout the article. Only two poems from this book have been translated into English. These are "Trick" and "Running", translated by Csilla Hajnal Nagy and published on the author's website: https://annaterek.wordpress. com/2019/08/19/trick/ and https:/annaterek.wordpress.com/2019/08/19/running/ (Last accessed 29 June 2021). 
place in different places and at different times - one might have the impression that temporal references are blurred, even to the extent of moments sensed as being out of time - and the women differ in age, nationality, and personal life experience, we can say that we are dealing with the stories taking place in Eastern Europe in the second half of the $20^{\text {th }}$ century, with particular emphasis on the importance and consequences of the war in the Balkans. It would seem that such a precise historical and social context will limit Terék's poetry. Nevertheless, this does not happen. Terék manages to create poems that go beyond the framework of any specific socio-historical context, because at the heart of the book there lies the paradigm of the victim - or even the victim-perpetrator dichotomy -, the paradigm that is above any specific socio-historical framework and tends to be often neglected in social discourses. Trauma, precisely the experience that leads to it, is situated within the broad contexts of war, toxic family relationships, patriarchy, rape, illness, religious fanaticism, and loneliness, and it requires a specific form of narration. This points towards the idea of the collective narration, where the polyphonic nature of individual lyrical subjects creates a new narrative quality - the collective voice of women that bears witness to their lives. Thanks to that, the book gains a universal dimension that resonates with the reader.

The image of a woman that emerges from the poems is unambiguous - in Halott nók, the woman is trapped in a world that is distant, even hostile to her. It is a world in which she is tied to her surroundings - man, family, and social expectations. In this world, a woman is weak, powerless, unable to fight, passive, even apathetic. She is unable to fully define herself, to gain her own identity with which she could resist and overcome the suffering that is inflicted upon her. In this world, she is to live silently and must succumb to the will of others: "He's mad at me because / I'm not quiet enough, / I can't live / silently" (Terék 2017, 64). Paradoxically, only death gives her the strength to articulate the pain and suffering, thanks to which she regains her own voice. It is the woman's power now to narrate her life. She can finally express the truth of her existence, and thus she takes steps towards liberation from the suffering that imbued her life.

At this point, several questions emerge: are these stories/portraits of women limited only to a stereotypical view of social roles? Does this picture of the fate of women not seem to be exaggerated? Is the opposition between men and women not too radical here? The answer to all these questions is no. Although the author delimits social roles quite precisely, she does not do it arbitrarily. On the contrary - poems are written from a perspective in which one can clearly feel empathy, which might be called social, or simply human, empathy. Despite the fact that women are the protagonists of the book, men also get their place in it. The fate of men is closely related to the fate of women, but we get to know them mostly from the perspective of women. We meet men who have succumbed to alcoholism, used physical as well as psychological violence against their loved ones, men 
who are lovers and men who are cheated on, men whose dreams and hopes have not come true. We also meet fathers who oppress their sons or who simply do not know how to play the role of a parent, and finally little boys who are taught from an early age to live in a society where violence is the norm. The only man who is given a voice as a lyrical subject is Gašpar from the cycle "Island". His monologue is also the poem closing the entire book. The lyrical subject tells the story of the betrayal from his own perspective, but, interestingly, there is no negation of the female perspective. Rather, there is a complete inability to understand and self-reflect, which is caused by the strongly imposed framework of religious and social norms. Men also become prisoners and victims of the norms, expectations, and social requirements of a given culture. It is also their fate that we see as tragic. It should be noted, however, that Terék does not take responsibility from the shoulders of the perpetrators - whether it is a soldier raping a girl, a fanatical husband, or a toxic mother. However, the author shows the multifaceted nature of human existence and the fact that humans are social beings. And trauma, as much as it touches an individual's fate, often has a social background, even when society ignores and rejects the unpleasant and inconvenient, and refuses to deal with its dark side.

\section{Language and Narration}

One of the fundamental issues in the literary representation of trauma is that of the language used to describe the most extreme experiences. Each time this language has to be re-invented. As Anna Menyhért emphasizes, literary language cannot remain silent about trauma, nor can it hide it, but at the same time it must show that the current language is inappropriate to talk about trauma. Menyhért speaks of the necessity to show and preserve this (linguistic) break in literature because only then will it be possible to create a connection between the past and the present and thus validly speak of trauma. This new language must, therefore, get rid of gullibility and naivety (Menyhért 2008, 6). In return, it must offer distrust and challenge the status quo to break the silence. The language of trauma must respect the individuality as well as the fragmentary, incomplete, and active nature of memory, which does not negate suffering or the traumatic experience itself. At the same time, it has to demand an answer. Such a language can create literature. The act of literary telling, which requires then the act of listening (reading), allows the individual to articulate the "unspeakable". Literature - both fiction and non-fiction - not only enables the recognition of a particular individual trauma but also makes it possible to grasp it on a bigger scale and arouse the awareness of social, cultural, and political factors that lead to trauma. And, by doing so, it also offers a better understanding of individually and collectively 
experienced trauma. This power of literary texts, the ability to express the most extreme experience, and literature's diversity of representational modes precede other cultural expressions of trauma.

As Joshua Pederson emphasizes, the discourse of trauma often means not silencing the traumatic experience but on the contrary - more intensive work of the memory in order to recall the smallest details from the past (Pederson 2014, 339). Of course, this does not mean linearity or completion of the narrative (memory). However, recalling, remembering a traumatic experience and articulating suffering, making it present, can help and can bring relief, i.e. incorporate the traumatic experience into the self-image, which has both psychologically and epistemologically positive consequences. ${ }^{3}$

In Halott nók, Terék creates a new and adequate "language of trauma" that unfolds in an authentic and natural way to tell about the suffering experienced by the protagonists. It is a minimalistic poetry that uses simplicity, language naturalness, concreteness and ellipsis as its main elements. Poems - monologues are associative in their nature because the lyrical subject selectively draws from past events. As critics point out, they can also be referred to as short stories because the language does indeed gravitate towards prose in many places (Förköli 2018, 112; Kustos 2018, 52). Lyrical subjects find their own way to express trauma and articulate suffering, which, at the same time, means that they gain subjectivity and identity. This necessity to express oneself, finding the right words for one's story, and thus obtaining identity and individuality even in the face of death is also emphasized in many places in the poems, e.g. when speaking to God, one of the protagonists says: "I try to find the right words for you, / but they all are falling out of my mouth" (Terék 2017, 125). Nevertheless, the language, in many places very naturalistic, turns out not to be an obstacle but a means by which the characters manage to articulate their suffering. This is achieved using very few, though coherent, stylistic devices.

One of the most important, if not the most important technique, which in a sense takes over the role of the main stylistic device, is fragmentation at the conceptual, structural, thematic, and lyrical levels alike. At the level of the poems' structure, the author uses this technique very consciously. First of all, the cycles/monologues do not form a linear story but have a rhapsodic structure (Gorove 2018, 79) - one memory evokes another, and yet another; time is blurred. The stories told are not "full", but they fully show the enormity of the

3 Looking at trauma as something unspeakable and unrepresentable, which is contradictory on the level of experience and language, is characteristic of the first wave of trauma studies developed around Cathy Caruth's model. Through the diversity of narrative (artistic) expressions, the view presented in this paper, i.e. that traumatic experience, can contribute to the knowledge of the self and of the external world - and show at the same time the cultural conditioning of trauma -; it is closer to the research developed within the pluralistic theory of trauma (Balaev 2018, 366-367). 
pain and suffering experienced. Also, the very structure of individual poems (or fragments) is of a similar nature - the lines are usually short, end in enjambment, and are "broken" (also in the typographic sense), which reflects more clearly and emphasizes the fates that are told. At the same time, enjambment plays a role in slowing down and building up tension, thanks to which the train of thought gets a stronger, often unexpected ending. As a result, the author elaborates a more dynamic language in spite of the static character of content and metaphors. This fragmentation, or "fracture", appears in many places in the text also on a lyrical level - it is a metaphor of the disintegration of one's personality and impending death, which is the key issue in the entire book (see examples listed in the next section of this paper).

This technique can be seen, for example, in an excerpt from the "Jelena" cycle, which begins with the words "My Dad...". In this fragment, we learn many details about the life of Jelena's dad, we get to know him and the whole family, we get to know his youth, even the fact that he failed a microeconomics exam in college and thus he was afraid to go home. We also learn about the difficult relationship between Jelena and her father - he is ashamed she is not a boy, he never tells her she is pretty, etc. The repeated phrase "my dad" is fully completed only at the very end of the poem - we learn that Jelena's dad was shot by "two laughing soldiers". We also get to know the reason why this happened - because he "knocked out a little Bosnian girl's twenty-eight teeth with a gunstock" (Terék 2017, 15). The attempt to ignore or forget this event is ineffective - the lyrical subject admits that in the end she has to face what her dad did. This little Bosnian girl turns out to be Maja, the character we get to know later, and we can precisely see what Jelena's father has done in the poem "With a Gunstock".

It is worth paying attention to the specific varieties of the "language of trauma" in Halott nók. This language changes in different cycles and adopts separate varieties which correspond with changing lyrical subjects. From this perspective, attention should be paid to the cycle entitled "Maja", where the lyrical subject is a little girl and the language reflects this content - the language is sometimes naive, sometimes evidently repeating the words of adults that the girl must have heard (like in the poem "Naughty"), and, above all, it shows how, in the eyes of a child, war becomes something normal, something that one gets used to when they experience it every day. We can also speak of a special tone in the case of the last cycle of the book, i.e. in the poem "Gašpar", which in its fragments imitates a prayer stanza, showing the widower's religious fanaticism. 


\section{Motifs}

The above-emphasized homogeneity of the entire book on the lyrical level means that the traumatic experiences of the five protagonists have been described using a homogeneous but extensive network of motifs, metaphors, comparisons, and repetitions. First of all, the overriding and very broadly understood motif of death must be emphasized. It should be pointed out that death does not only affect the heroines themselves but also their relatives (children, family members) and people who are complete strangers to them, which is part of the perspective of the collective narrative: "I'm going to die / like anyone else" (Terék 2017, 68). The poems also radically show the parent's suffering caused by the death - as a result of illness, war, accident - of the child and the inability to deal with this experience and to express it in words. However, as understood in Halott nók, death does not only mean physical death - not all lyrical subjects speak from beyond the grave. Death is also a metaphor of passivity, helplessness, deprivation of one's voice, deprivation of one's life. It is associated with total resignation, e.g.: "let it be finally over" (Terék 2017, 108), and brings relief from suffering, e.g.: "I would like to / kill her, so she won’t have to suffer any more” (Terék 2017, 48). In many places we read that the women are to live without any movement, without any sound, that a static and overwhelming force pulls them down and makes it impossible for them to move, which can be understood as the sign of impending death. Yet, there is no doubt - death does not bring happiness, death is the final state from which there is no escape or return.

One of the clearest metaphors of death is the picture of breaking into pieces, of (physical and mental) fracturing and disintegration - more precisely: one's life is breaking into small pieces that can no longer be put together:

I tried / to pay less and less attention / that I should fall, and break into small splinters / together with my stripped bones. (Terék 2017, 17)

While crying, my mother annihilates / all, still intact / ideas about how she will live. (Terék 2017, 33)

I broke in two like the sausages, / if you prick the fork into them. / Right in the middle. (Terék 2017, 37)

I have torn / into tiny parts / from the inside. / Like splinters, they sting in my circulatory system / and my heart / when I lie on my side. (Terék 2017, 37-38)

The death / shatters the bodies / into tiny, soft pieces. (Terék 2017, 70)

The sky leans over me / pushes my shoulders, / splinters chip off the edge of my spine. (Terék 2017, 124) 
Dreams, plans for the future, and life itself are broken. The female body is broken. Decay, as clearly visible in the above quotes, is often correlated with the metaphors of the body and corporeality. The body in Halott nók is the "defeated body" (Terék 2017, 30). Mental suffering is strongly and intangibly related to perceived physical suffering. Death puts an end to the human body, which is after all limited and finite, as in the poem "Death", which vividly shows how individual parts of the body gradually atrophy in the face of impending death. It can even be said that in Terék's poems it is the body that rules our existence, and we are at the mercy of its physicality. The passing of life manifests itself in drying up, creaking, fracturing, and breaking: "I keep getting dry, getting / more and more fibrous, / creaking inside with every turn" (Terék 2017, 130). The body, as a separate being, is the vector of memories and images from the past that mark the human psyche: "Because the child dies in vain, / nothing ever happens after that. / In the heart remains a crack, / and in that crack settles fear" (Terék 2017, 10) or "My body remembers / reminds me / creaking" (Terék 2017, 37).

Death also means war. In one of the book's most shocking poems, these three elements come together. "With a Gunstock" tells the story of a gang rape of a young Bosnian girl. The poem begins with a familiar metaphor: "I don't have anything / that can still be broken" (Terék 2017, 93). Then the picture of breaking the body into tiny pieces is repeated: "I'm afraid that they will break my bone, totally crash my joints, / and I won't be able to run away, / or if I get caught in the meantime, / others will smash everything / inside me" (Terék 2017, 93-94). Next, the poem moves on to the comparison of a weapon to a penis, and to the rape scene where the motif of gaze, which is present also in other poems, plays an important role. An equally shocking comparison is the comparison of the sounds of a bombardment to the sounds of a heartbeat that an unborn baby hears in the mother's womb.

It is also important to emphasize the semantics of the body, which stresses the body as a whole, but also its individual parts, especially the eyes, mouth, and nose. In Halott nók, the body is presented as meat (Terék 2017, 17, 25), parts of which are easily destructible: they break, fall off, dry out. Both physical and mental pain are present at every level of the narrative. The motif of eyesight is most ambiguous here. Eyes indicate the eyesight with which you look at something, the blurry gaze of a drunk little boy, the eyes of a man expressing his desire, the eyes of the protagonists expressing pain and helplessness. It is watching people being executed in the streets, it is looking into the vastness of Siberia, which makes you blind, it is an attempt to find a wife's lover in the eyes of strangers. Or on the contrary, it is looking away from something that is beyond understanding and accepting: "My eyes faded forever" (Terék 2017, 32) or "They didn’t allow him to continue looking at my body. / So I also turned away" (98). 
The mouth, in turn, is related to swallowing, which also functions as a metaphor in various ways: it is the swallowing of pain, the digesting of what is happening, it is annihilation, swallowing the son, but also pieces of a broken window, city, or the whole family, which expresses fear and helplessness. It is also the mouth uttering and spitting out words of a prayer or the mouth of a dead wife that is full of sand. The sense of smell is also strongly associated with suffering - this motif opens the book, and it is correlated with Jelena's suicide. At the beginning, the smell of gas is pleasant for Jelena, but at the end it brings death. Also, in the next parts of the book, smell is identified as the smell of death, symbolizing decay spreading throughout the body and absorbing it.

These, as well as other motifs, structural fragmentation, and thematic repetitions - like the theme of conversation with God; the oxymoronic theme of home, not as a place where one finds happiness and security but pain and suffering; the theme of parents unable to help their children; the theme of toxic relationships with parents; the theme of abandonment; the theme of uprooting and emigration; etc. - provide the strength of the book. The intensity of the images is based on the directness of the language on the one hand and on the thematic repetitions which contribute to the cohesion and dynamism of the poems on the other.

\section{Conclusions}

Although Terék's book might be qualified as feminist literature, the author herself does not follow this path directly despite the fact that she shows different spheres of physical and mental violence committed on women, which have their source in the socio-economic and historical cultural context. The psychological level of the entire book demonstrates the processes that lead to deprivation of integrity and, as a result, to the tragic end of the protagonists. The fragility of a human being is shown here from many perspectives. Different voices enter into dialogue, interact with each other, and reveal the depth and complexity of human fate. At the same time, the author shows with great empathy that the world is not black and white. However, she does not absolve anybody of guilt and responsibility. The book shows that suffering and trauma, apart from affecting individual fates, also possess a social dimension because they are the consequences of the relations within a given society and culture, the lack of social empathy as well as often unconscious mechanisms of compulsion and violence which in times of war, or simply crisis, become even stronger and exacerbate social inequalities. The past, with its traumatic experiences that affect society, demands an effort of talking about the past, because only articulating these experiences can bring healing. Otherwise, passivity and silence only maintain the status quo, or even deepen it. Individual and collective trauma demands gaining a voice, demands 
its own narrative. Terék manages to find this voice. Halott nók, directly but also empathically, with moderation and sensitivity towards individual fates, tells about the trauma that can be historically localized. But, at the same time, this voice remains universal and resonates outside the author's cultural background.

\section{Works Cited}

Balaev, Michelle. 2018. "Trauma studies". In A Companion to Literary Theory, ed. David H. Richter, 360-371. Chichester, West Sussex: Wiley Blackwell.

Förköli, Gábor. 2018. "Halottas ének és minimalista hangszerelés (Terék Anna: Halott nők)" [The Lament with Minimalist Orchestration (Anna Terék: Dead Women)]. Esố irodalmi lap vol. 21, no. 1(Tavasz): 111-113.

Gorove, Eszter. 2018. "Síron túl (Terék Anna: Halott nők)" [Beyond the Grave (Anna Terék: Dead Women)]. Müút vol. 63, no. 66: 78-80.

Görföl, Balázs. 2017. "Fekhelyek szilánkokon (Terék Anna: Halott nők)” [Lairs on the Splinters (Anna Terék: Dead Women)]. Tiszatáj vol. 71, no. 11: 121-123.

Kustos, Júlia. 2018. “A szilánkok fraktálképe. Terék Anna: Halott nők” [The Fractal Image of Splinters. Anna Terék: Dead Women]. Új Forrás vol. 50, no. 9: $48-52$.

Masters, Edgar Lee. 1992. Spoon River Anthology. Norwalk: The Easton Press.

Menyhért, Anna. 2008. Elmondani az elmondhatatlant [Speaking the Unspeakable]. Budapest: Anonymus-Ráció.

Pataky, Adrienn. 2017. "Lírai kiengesztelődés. Terék Anna: Halott nők” [Lyrical Reconciliation. Anna Terék: Dead Women]. Alföld vol. 68, no. 12: 107-113.

Pederson, Joshua. 2014. "Speak, Trauma: Toward a Revised Understanding of Literary Trauma Theory”. Narrative vol. 22, no. 3: 333-353.

Terék, Anna. 2017. Halott nók [Dead Women]. Novi Sad: Forum - Budapest: Kalligram. 